\title{
Second-generation inhibitors of Bruton tyrosine kinase
}

\author{
Jingjing Wu' ${ }^{1}$ Christina Liu², Stella T. Tsui ${ }^{3}$ and Delong Liu ${ }^{1 *}$
}

\begin{abstract}
Bruton tyrosine kinase (BTK) is a critical effector molecule for B cell development and plays a major role in lymphoma genesis. Ibrutinib is the first-generation BTK inhibitor. Ibrutinib has off-target effects on EGFR, ITK, and Tec family kinases, which explains the untoward effects of ibrutinib. Resistance to ibrutinib was also reported. The C481S mutation in the BTK kinase domain was reported to be a major mechanism of resistance to ibrutinib. This review summarizes the clinical development of novel BTK inhibitors, ACP-196 (acalabrutinib), ONO/GS-4059, and BGB-3111.

Abbreviations: $A E$, adverse event; $B T K$, Bruton tyrosine kinase; $C R$, complete response; ORR, overall response rate; PR, partial response; SD, stable disease; DLT, dose-limiting toxicity; MTD, maximal tolerated dose
\end{abstract}

\section{Background}

\section{Bruton tyrosine kinase}

Bruton tyrosine kinase (BTK) was initially implicated in the pathogenesis of X-linked agammaglobulinemia [1-4]. The gene encoding the BTK molecule was isolated in 1993 and was named independently at the time as B cell progenitor kinase and agammaglobulinemia tyrosine kinase $[5,6]$. The BTK gene is located on the X chromosome in the region Xq21.3-22.1. The gene contains 19 exons and the open reading frame has 1977 nucleotides. BTK is a 76-kDa polypeptide with 659 amino acid residues.

\section{BTK functions}

BTK is expressed in the cells of all hematopoietic lineages except for $\mathrm{T}$ and plasma cells [7]. It is a cytoplasmic tyrosine kinase in the Tec family [8]. Like other Tec family members, BTK has a PH (pleckstrin-homology) domain, SH3 and SH2 (src-homology) domains, and a carboxyl kinase domain (Fig. 1). This tyrosine kinase lies downstream of the $\mathrm{B}$ cell antigen receptor (BCR) [9]. Upon activation of BCR, BTK becomes activated through interacting with the partner molecules through the $\mathrm{PH}$ and $\mathrm{SH}$ domains $[10,11]$. This in turn leads to calcium release $[8,12]$. BTK is a critical effector molecule and is involved in all aspects of B cell

\footnotetext{
* Correspondence: DELONG_LIU@NYMC.EDU

'Department of Oncology, The first Affiliated Hospital of Zhengzhou

University, Zhengzhou 450052, China

Full list of author information is available at the end of the article
}

development, including proliferation, maturation, differentiation, apoptosis, and cell migration [13]. When the BTK gene was knocked out in a mouse model, a reduced number of mature B cells along with severe IgM and IgG3 deficiency were observed [14]. BTK is critical in the initiation, survival, and progression of B cell lymphoproliferative disorders [15-17].

\section{Ibrutinib: the first-generation BTK inhibitor}

Targeting novel biomarkers that are driver molecules regulating cancer cell growth and differentiation has revolutionized drug development for cancer therapy [18-24]. Novel agents targeting biomarker molecules in lymphocytes are revolutionizing treatment of lymphoid malignancies [25-33]. Since BTK is a critical effector molecule for B cell development and plays a major role in lymphomagenesis, BTK inhibitors have been investigated as potential treatments [11, 34-37]. To date, ibrutinib remains the only BTK inhibitor approved for several lymphoproliferative malignancies [38-40].

Ibrutinib is the first-in-class, highly potent small molecule inhibitor that selectively binds to cysteine 481 residue in the allosteric inhibitory segment of BTK kinase domain. The compound irreversibly abrogates the full activation of BTK by inhibiting its autophosphorylation at tyrosine residue 223 [41]. Ibrutinib (imbruvica) has been approved for the treatment of chronic lymphocytic leukemia (CLL), mantle cell lymphoma (MCL), and Waldenstrom's macroglobulinemia [11, 35, 36, 38-40, 42-46]. 


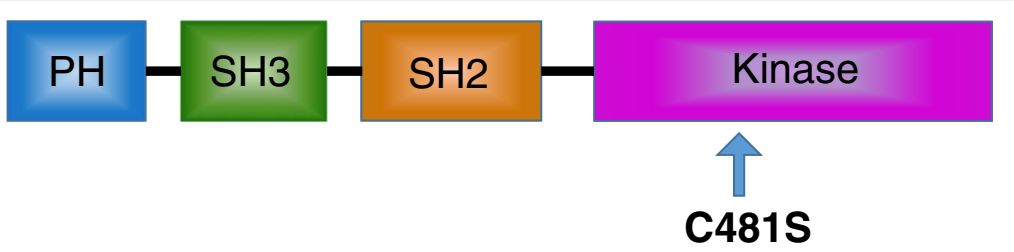

Fig. 1 The structure of Bruton tyrosine kinase (BTK). BTK has a pleckstrin-homology (PH) domain, SH3 and SH2 (src-homology) domains, and a kinase domain. The BTK polypeptide has 659 amino acid residues with an approximate molecular weight of $76 \mathrm{kDa}$. The C481S mutation in the kinase domain mediates resistance to ibrutinib

However, untoward effects, such as bleeding, rash, diarrhea and atrial fibrillation have been observed and attributed in part to its off-target effects on the epidermal growth factor receptor and the Tec family proteins other than BTK $[8,43,44,47-53]$. In addition, resistance to ibrutinib has been observed $[54,55]$. As a result, second-generation BTK inhibitors are being developed.

\section{Resistance mechanisms for ibrutinib}

The estimated progression-free survival (PFS) rate among relapsed/refractory CLL patients treated with ibrutinib was reported to be $75 \%$ at 26 months [38]. The mechanisms of acquired resistance to ibrutinib are under active investigation [54-56].

In one case report, a CLL patient developed resistance after 21 months on ibrutinib at a dose as high as $840 \mathrm{mg}$ daily [55]. Through sequencing RNA from pre- and post-treatment samples, a thymidine-to-adenine mutation at nucleotide 1634 of the BTK complementary DNA (cDNA) was discovered. This led to a substitution of serine for cysteine at residue 481 (C481S) (Fig. 1). Ibrutinib forms a covalent bond with the sulfhydryl group of C481 of BTK and irreversibly inhibits the kinase activity of BTK [41]. The new amino acid residue S481 prevents ibrutinib from covalently binding to the BTK mutants, converting irreversible inhibition of the BTK to reversible inhibition. When the phosphorylation at tyrosine residue 223 was studied, the IC50 (half-maximal inhibitory concentration) of ibrutinib changed to $1006 \mathrm{nM}$ on C481S mutant BTK from $2.2 \mathrm{nM}$ on nonmutant BTK [55]. The C481S mutation was below the detectable level in ibrutinib-naïve patients, suggesting that this mutant clone was selected out through BTK inhibition by ibrutinib [57]. The same C481S BTK mutation was also found to be responsible for acquired resistance to ibrutinib in MCL $[56,58]$.

In addition to the C481S mutation, three distinct mutations in PLC $\gamma 2$ were found in two CLL patients who became resistant to ibrutinib [54]. Two mutations in PLC 2 2, R665W and L845F, could lead to a gain-offunction. Since PLC 2 lies immediately downstream of BTK, these mutants could therefore bypass the inactive
BTK and allow autonomous B cell receptor activity despite the inactive BTK. In an update, two of six patients with Richter transformation after ibrutinib therapy had the BTK C481S mutation, while $100 \%$ patients $(10 / 10)$ with progression but no Richter transformation had either one or both BTK C481S and PLC 22 mutations [54]. None of the mutations were present in any of the patients with prolonged lymphocytosis on ibrutinib therapy.

Approximately $32 \%$ of MCL patients had primary resistance to ibrutinib since the response rate of $\mathrm{MCL}$ to ibrutinib was $68 \%$ [40]. This suggests that additional mechanisms of resistance exist. It was demonstrated that inhibition of ERK1/2 and AKT correlated with cellular response to BTK inhibition in vitro and in primary tumor samples [58]. Taken together, primary ibrutinib resistance in MCL is not mainly caused by ineffective ibrutinib inhibition of BTK but rather involves PI3K-AKT activation. In addition, transcriptome sequencing displayed recurrent mutations in TRAF2 or BIRC3 in $15 \%$ of the 165 patient samples [59]. These genetic lesions in the alternative NF-kB pathway exposed another mechanism of primary ibrutinib resistance in MCL.

In patients with Waldenstrom's macroglobulinemia (WM), MYD88 and CXCR4 mutations have been shown to be associated with clinical response to ibrutinib [46, 60, 61]. The effect of MYD88 and CXCR4 mutations on outcomes of ibrutinib in 63 patients with WM was reported [39, 46]. Results indicate that patients with MYD8 $8^{\mathrm{L} 265 \mathrm{P}} \mathrm{CXCR} 4{ }^{\mathrm{WT}}$ have the highest response rate (100\% overall response rate). BCL2 can protect against ibrutinib triggered apoptosis regardless of CXCR4 ${ }^{\text {WHIM }}$ mutation status $[60,62]$, supporting the use of BCL2 inhibitor in refractory B cell malignancies [19].

There is, however, no relationship between MYD88 mutation status and ibrutinib response in patients with diffuse large B cell lymphoma (DLBCL), particularly the $A B C$ subtype. Instead, mutations that affect the signaling of $B$ cell and $T$ cell receptors, such as CD79A/B and CARD11 may be responsible for lower response to ibrutinib [39, 63, 64]. 


\section{Second-generation BTK inhibitors}

The emerging resistance to and off-target side effects of ibrutinib have led to active development of secondgeneration and more specific BTK inhibitors, such as ACP-196, ONO/GS-4059, and BGB-3111.

\section{ACP-196}

ACP-196, also known as acalabrutinib, is a novel irreversible second-generation BTK inhibitor [34, 37]. It is more potent and selective than ibrutinib with reduced off-target side effects. As shown through IC50 determinations on nine kinases with a cysteine residue in the same position as BTK, ACP-196 had virtually no inhibition on kinase activities of EGFR, ITK, TEC, etc. [37, 65, 66].

A phase 1/2, multicenter, open-label, and doseescalation clinical trial on ACP-196 (NCT02029443) has been underway in relapsed and refractory CLL patients. In the last update, 61 patients with relapsed CLL were enrolled [37]. In the phase 1 portion of this study, patients were treated with ACP-196 at an increasing dose of 100 to $400 \mathrm{mg}$ once daily, while in the phase 2 expansion portion, $100 \mathrm{mg}$ twice daily was given. The median follow-up time was 14.3 months (range $0.5-20$ ), the overall response rate (ORR) was $95 \%$, with $85 \%$ partial response (PR), $10 \%$ $\mathrm{PR}$, and $5 \% \mathrm{SD}$ (stable disease). Among them, patients with chromosome 17p13.1 deletion had $100 \%$ ORR. The most common adverse events were headache, diarrhea, and weight gain, without dose-limiting toxicities, and no cases of atrial fibrillation and Richter's transformation.

Currently, a phase 3 study (NCT02477696) directly comparing ACP-196 with ibrutinib in high-risk patients with relapsed CLL has commenced. In addition, multiple trials of ACP-196 on other hematological malignancies and solid tumors are underway [34].

\section{ONO/GS-4059}

ONO/GS-4059 is another highly potent and more specific BTK inhibitor. Its anti-tumor activities were studied in preclinical models [67] and in the clinical trials for the treatment of $B$ cell malignancies [68-73].

In an ABC-DLBCL cell line (TMD-8) xenograft model, the effects of ONO/GS-4059 on gene transcription in vivo were analyzed [67]. The results indicated that ONO/GS-4059 affects a core set of genes that contain nine down-regulated and eight up-regulated genes in a dose-dependent manner. Among these, CXCL-10 is the most down-regulated gene by ONO/GS-4059 and is involved in the pathological processes of human disorders, such as infectious diseases and inflammatory and autoimmune diseases as well as cancer. This study confirmed the profound anti-proliferative activity of ONO/GS-4059 by inhibiting BTK in the TMD- 8 model.

The first-in-human phase I study of ONO/GS-4059 was on relapsed/refractory B cell malignancies (NCT01659255)
[70]. The efficacy and safety data on 90 evaluable patients (CLL $n=28$, MCL $n=16$, DLBCL $n=35$, FL $n=5$, WM $n=3$, MZL $n=2$, and SLL $n=1$ ) were reported [68-70, 72]. The dose-escalating $3+3$ cohorts ranged from $20 \mathrm{mg}$ to $600 \mathrm{mg}$ once daily, and twice-daily regimens had doses of $240 \mathrm{mg}$ and $300 \mathrm{mg}$. In the CLL group, $96 \%(24 / 25)$ of patients had objective responses within the first 3 months of therapy. Rapid responses in the lymph nodes were noted with concurrent lymphocytosis [72]. In the MCL group, $92 \%$ (11/ 12) of patients responded to ONO/GS-4059 (six PR and five complete responses (CRs)/Cru). In non-germinal center DLBCL, 35 \% (11/31) of patients responded with 2 confirmed CR, $1 \mathrm{CRu}$, and $8 \mathrm{PR}$. In contrast to CLL and MCL, responses of DLBCL were much less durable. Notably, CLL and MCL patients with a chromosome 17p deletion and/or TP53 mutation as well as those following allogeneic stem cell transplantation responded rapidly. The pharmacokinetics of ONO/GS-4059 showed rapid absorption and elimination with a half-life of 6.5 to $8 \mathrm{~h}$. The BTK occupancy in the peripheral blood was maintained for at least $24 \mathrm{~h}$ across all dose levels. Most importantly, ONO/GS-4059 was found to be well tolerated in all groups. There was no maximal tolerated dose (MTD) reached in the CLL group. In the lymphoma cohort, $480 \mathrm{mg}$ once daily was the MTD. Drugrelated hematoma was reported in one patient. Atrial fibrillation was observed, but it was reported to be not drug-related [72]. In the kinomescan study, ONO/GS-4059 was found to have significantly weaker activity on TEC kinase [72]. Therefore, ONO/GS-4059 has a favorable safety profile along with preliminary efficacy in patients with relapsed/refractory B cell malignancies.

Further investigations of ONO/GS-4059 are ongoing to ascertain its advantages in combination therapies. Combination of idelalisib and ONO/GS-4059 synergistically inhibited the growth of a subset of DLBCL and MCL cell lines [71]. This combination led to more significant growth inhibition of the A20 mutant TMD8 cells than single agent idelalisib. This suggested that the combination therapy may overcome some mechanisms of resistance in the BTK signaling pathway. In addition, Jones et al. investigated the potential activity of combinations of the $\mathrm{B}$ cell receptor pathway inhibitors, entospletinib, ONO/GS4059, and idelalisib, with the BCL2 inhibitor ABT-199 in primary CLL cells [73-76]. Results showed that their combination synergistically increased the apoptosis in these primary CLL cells and achieved the maximal levels of apoptosis. These data support clinical investigation of these combinations in patients with CLL.

\section{BGB-3111}

BGB-3111 is another more selective BTK inhibitor with superior oral bioavailability, higher BTK specificity than ibrutinib [24, 77]. 
Table 1 Comparison of ibrutinib with second- generation BTK inhibitors

\begin{tabular}{lllll}
\hline & Ibrutinib & ACP-196 & ONO/GS-4059 & BGB-3111 \\
\hline Target & BTK & BTK & BTK & BTK \\
Major off-targets & EGFR, ITK, TEC & Minimal & TEC (weak) & ITK (weak) \\
Activity on C481S & No & Yes & Yes & Yes \\
Platelet inhibition & Yes & No & NA & NA \\
Atrial fibrillation & Observed & Not observed & Observed & NA \\
Approved indications & CLL/SLL, MCL,WM & None & None & None \\
\hline
\end{tabular}

BTK Bruton tyrosine kinase, NA not available /reported, CLL chronic lymphoid leukemia, SLL small lymphoid leukemia, MCL mantle cell lymphoma, WM Waldenstrom's macroglobulinemia

${ }^{a}$ The atrial fibrillation was not thought to be drug-related

In preclinical studies, BGB-3111 showed more restricted off-target activities against a panel of kinases, including ITK. Due to the weaker activity on ITK, BGB3111 was at least 10 times weaker than ibrutinib in inhibiting rituximab-induced ADCC activity. Both in the REC-1 MCL and ABC subtype DLBCL (TMD-8) xenograft models, BGB-3111 induced dose-dependent antitumor effects and demonstrated superior efficacy in comparison with ibrutinib. Toxicity study in rats indicated that BGB-3111 was very well tolerated, and the MTD was not reached when it was dosed up to $250 \mathrm{mg} /$ $\mathrm{kg} /$ day [77]. These preclinical data showed that BGB3111 is a highly selective and potent BTK inhibitor.

The first-in-human, open-label phase 1 trial of BGB3111 is ongoing as a modified $3+3$ dose-escalation design (40, 80, 160, $320 \mathrm{mg}$ PO QD; $160 \mathrm{mg}$ PO BID) in patients with advanced $B$ cell malignancies [24]. The pharmacokinetics, efficacy and safety of BGB-3111 were assessed in this study. At the last update from the 2015 ASH annual meeting, 25 patients were enrolled in five cohorts: $40 \mathrm{mg}(n=4), 80 \mathrm{mg}(n=5), 160 \mathrm{mg}(n=6)$, $320 \mathrm{mg}(n=6)$ QD, and $160 \mathrm{mg}$ BID $(n=4)$. Sixty-four percent $(16 / 25)$ of patients had objective responses, including $1 \mathrm{CR}$ and $6 \mathrm{SD}$. There were no drug-related adverse events (AEs), no dose-limited toxicities (DLT) reported yet, and the MTD was not reached. The preliminary phase 1 results suggested that the selective BTK inhibitor BGB-3111 is clinically active and tolerable. However, the study report was preliminary, and its toxicity profile and clinical efficacy remain to be determined.

\section{Conclusions}

Second-generation and more selective BTK inhibitors, ACP-196, ONO/GS-4059, and BGB-3111, are being evaluated clinically. These compounds have fewer offtarget effects and are more potent than ibrutinib (Table 1). Ibrutinib has been shown to be well tolerated and effective in combinations with chemotherapy regimens $[78,79]$. The more selective ACP-196 and ONO/ GS-4059 are being investigated in combinations with active agents in lymphoma therapy. With the advances in bispecific antibodies [80-83], antibody drug conjugates [84, 85], immune checkpoint blockers [86, 87], and CAR-T for cancer immunotherapies [88-90], further investigation of combinations with these agents will lead to less toxic and more targeted therapeutic regimens for B cell malignancies.

\section{Acknowledgements \\ Jingjing Wu is a recipient of the Henan Provincial Grant for Overseas Research for Young Leaders of Medical Technology (No. 2014041). She also received grant support from the Natural Science Foundation of China (NSFC No. 81201793). The grants supported her research training at the Division of Hematology and Oncology, New York Medical College and Westchester Medical Center, Valhalla, NY, USA.}

Availability of data and materials

The material supporting the conclusion of this review has been included within the article.

\section{Authors' contributions}

DL designed the study. JW and DL drafted the manuscript. CL and ST participated in the manuscript preparation and revisions. ST and DL designed and finalized the figure. All authors read and approved the final manuscript.

\section{Competing interests}

The authors declare that they have no competing interests.

\section{Consent for publication}

This is not applicable for this review.

\section{Ethics approval and consent to participate}

This is not applicable for this review.

\section{Author details}

${ }^{1}$ Department of Oncology, The first Affiliated Hospital of Zhengzhou University, Zhengzhou 450052, China. ${ }^{2}$ Weinberg College of Arts and Sciences, Northwestern University, Evanston, IL 60208, USA. ${ }^{3}$ SUNY Stony Brook University, Stony Brook, NY 11794, USA.

Received: 31 July 2016 Accepted: 26 August 2016

Published online: 02 September 2016

References

1. Bruton OC. Agammaglobulinemia. Pediatrics. 1952;9(6):722-8.

2. Vetrie $D$. Isolation of the defective gene in $X$ linked agammaglobulinaemia. J Med Genet. 1993;30(6):452-3.

3. Maas A, Hendriks RW. Role of Bruton's tyrosine kinase in B cell development Dev Immunol. 2001;8(3-4):171-81.

4. Valiaho J, Smith Cl, Vihinen M. BTKbase: the mutation database for X-linked agammaglobulinemia. Hum Mutat. 2006;27(12):1209-17. 
5. Tsukada S, Saffran DC, Rawlings DJ, Parolini O, Allen RC, Klisak I, Sparkes RS, Kubagawa H, Mohandas T, Quan S, et al. Deficient expression of a B cell cytoplasmic tyrosine kinase in human X-linked agammaglobulinemia. Cell. 1993;72(2):279-90

6. Vetrie D, Vorechovsky I, Sideras P, Holland J, Davies A, Flinter F, Hammarstrom L, Kinnon C, Levinsky R, Bobrow M, et al. The gene involved in X-linked agammaglobulinaemia is a member of the src family of proteintyrosine kinases. Nature. 1993;361(6409):226-33.

7. Smith Cl, Baskin B, Humire-Greiff P, Zhou JN, Olsson PG, Maniar HS, Kjellen P, Lambris JD, Christensson B, Hammarstrom L, et al. Expression of Bruton's agammaglobulinemia tyrosine kinase gene, BTK, is selectively down-regulated in T Iymphocytes and plasma cells. J Immunol. 1994;152(2):557-65.

8. Schwartzberg PL, Finkelstein LD, Readinger JA. TEC-family kinases: regulators of T-helper-cell differentiation. Nat Rev Immunol. 2005;5(4):284-95.

9. Wang K, Wei G, Liu D. CD19: a biomarker for B cell development, lymphoma diagnosis and therapy. Exp Hematol Oncol. 2012;1(1):36.

10. Saito K, Scharenberg AM, Kinet JP. Interaction between the Btk PH domain and phosphatidylinositol-3,4,5-trisphosphate directly regulates Btk. J Biol Chem. 2001;276(19):16201-6.

11. Novero A, Ravella PM, Chen Y, Dous G, Liu D. Ibrutinib for B cell malignancies. Exp Hematol Oncol. 2014;3(1):4.

12. Kurosaki T, Tsukada S. BLNK: connecting Syk and Btk to calcium signals. Immunity. 2000;12(1):1-5

13. Niiro H, Clark EA. Regulation of B-cell fate by antigen-receptor signals. Nat Rev Immunol. 2002;2(12):945-56.

14. Khan WN, Alt FW, Gerstein RM, Malynn BA, Larsson I, Rathbun G, Davidson L, Muller S, Kantor AB, Herzenberg LA, et al. Defective B cell development and function in Btk-deficient mice. Immunity. 1995;3(3):283-99.

15. Chiorazzi N, Ferrarini M. B cell chronic lymphocytic leukemia: lessons learned from studies of the B cell antigen receptor. Annu Rev Immunol. 2003;21:841-94

16. Kuppers R. Mechanisms of B-cell lymphoma pathogenesis. Nat Rev Cancer. 2005;5(4):251-62.

17. Lenz G, Staudt LM. Aggressive lymphomas. N Engl J Med. 2010;362(15): $1417-29$.

18. Smith A, Roda D, Yap T. Strategies for modern biomarker and drug development in oncology. J Hematol Oncol. 2014;7(1):70.

19. Cang S, Iragavarapu C, Savooji J, Song Y, Liu D. ABT-199 (venetoclax) and BCL-2 inhibitors in clinical development. J Hematol Oncol. 2015;8(1):129.

20. Das A, Wei G, Parikh K, Liu D. Selective inhibitors of nuclear export (SINE) in hematological malignancies. Exp Hematol Oncol. 2015;4(1):1-4.

21. Goede V, Fischer K, Busch R, Engelke A, Eichhorst B, Wendtner CM, Chagorova T, de la Serna J, Dilhuydy MS, IIImer T, Opat S, Owen CJ, Samoylova O, Kreuzer KA, Stilgenbauer S, Dohner H, Langerak AW, Ritgen M, Kneba M, Asikanius E, Humphrey K, Wenger M, Hallek M. Obinutuzumab plus chlorambucil in patients with CLL and coexisting conditions. N Engl J Med. 2014;370(12):1101-10.

22. Iragavarapu C, Mustafa M, Akinleye A, Furqan M, Mittal V, Cang S, Liu D. Novel ALK inhibitors in clinical use and development. J Hematol Oncol. 2015;8(1):17

23. Parikh K, Cang S, Sekhri A, Liu D. Selective inhibitors of nuclear export (SINE)- a novel class of anti-cancer agents. J Hematol Oncol. 2014;7(1):78

24. Tam C, Grigg AP, Opat S, Ku M, Gilbertson M, Anderson MA, Seymour JF, Ritchie DS, Dicorleto C, Dimovski B, Hedrick E, Yang J, Wang L, Luo L, Xue L, Roberts AW. The BTK inhibitor, Bgb-3111, is safe, tolerable, and highly active in patients with relapsed/refractory B-cell malignancies: initial report of a phase 1 first-in-human trial. Blood. 2015;126(23):832.

25. Breton C, Nahimana A, Aubry D, Macoin J, Moretti P, Bertschinger M, Hou S, Duchosal M, Back J. A novel anti-CD19 monoclonal antibody (GBR 401) with high killing activity against B cell malignancies. J Hematol Oncol. 2014;7(1):33.

26. Fan G, Wang Z, Hao M, Li J. Bispecific antibodies and their applications. J Hematol Oncol. 2015;8(1):1-14.

27. Rai K. Therapeutic potential of new B cell-targeted agents in the treatment of elderly and unfit patients with chronic lymphocytic leukemia. J Hematol Oncol. 2015;8(1):85.

28. Rai KR, Barrientos JC. Movement toward optimization of CLL therapy. N Engl J Med. 2014;370(12):1160-2.

29. Reusch U, Burkhardt C, Fucek I, Le Gall F, Le Gall M, Hoffmann K, Knackmuss SH, Kiprijanov S, Little M, Zhukovsky EA. A novel tetravalent bispecific TandAb (CD30/CD16A) efficiently recruits NK cells for the lysis of CD30+ tumor cells. mAbs. 2014;6(3):728-39.
30. Reusch U, Duell J, Ellwanger K, Herbrecht C, Knackmuss SH, Fucek I, Eser M, McAleese F, Molkenthin V, Gall FL, Topp M, Little M, Zhukovsky EA. A tetravalent bispecific TandAb (CD19/CD3), AFM11, efficiently recruits T cells for the potent lysis of CD19(+) tumor cells. mAbs. 2015;7(3):584-604.

31. Suresh T, Lee L, Joshi J, Barta S. New antibody approaches to lymphoma therapy. J Hematol Oncol. 2014;7(1):58.

32. Wu J, Fu J, Zhang M, Liu D. AFM13: a first-in-class tetravalent bispecific antiCD30/CD16A antibody for NK cell-mediated immunotherapy. J Hematol Oncol. 2015;8:96.

33. Wu J, Fu J, Zhang M, Liu D. Blinatumomab: a bispecific T cell engager (BiTE) antibody against CD19/CD3 for refractory acute lymphoid leukemia. J Hematol Oncol. 2015;8:104

34. Wu J, Zhang M, Liu D. Acalabrutinib (ACP-196): a selective secondgeneration BTK inhibitor. J Hematol Oncol. 2016;9(1):21.

35. Aalipour A, Advani RH. Bruton tyrosine kinase inhibitors: a promising novel targeted treatment for B cell lymphomas. Br J Haematol. 2013;163(4):436-43.

36. Advani RH, Buggy JJ, Sharman JP, Smith SM, Boyd TE, Grant B, Kolibaba KS, Furman RR, Rodriguez S, Chang BY, Sukbuntherng J, Izumi R, Hamdy A, Hedrick E, Fowler NH. Bruton tyrosine kinase inhibitor ibrutinib (PCl-32765) has significant activity in patients with relapsed/refractory B-cell malignancies. J Clin Oncol. 2013;31(1):88-94.

37. Byrd JC, Harrington B, O'Brien S, Jones JA, Schuh A, Devereux S, Chaves J, Wierda WG, Awan FT, Brown JR, Hillmen P, Stephens DM, Ghia P, Barrientos JC, Pagel JM, Woyach J, Johnson D, Huang J, Wang X, Kaptein A, Lannutti BJ, Covey T, Fardis M, McGreivy J, Hamdy A, Rothbaum W, Izumi R, Diacovo TG, Johnson AJ, Furman RR. Acalabrutinib (ACP-196) in relapsed chronic lymphocytic leukemia. N Engl J Med. 2016;374(4):323-32.

38. Byrd JC, Furman RR, Coutre SE, Flinn IW, Burger JA, Blum KA, Grant B, Sharman JP, Coleman M, Wierda WG, Jones JA, Zhao W, Heerema NA, Johnson AJ, Sukbuntherng J, Chang BY, Clow F, Hedrick E, Buggy JJ, James DF, O'Brien S. Targeting BTK with ibrutinib in relapsed chronic lymphocytic leukemia. N Engl J Med. 2013;369(1):32-42.

39. Treon SP, Xu L, Hunter Z. MYD88 mutations and response to ibrutinib in Waldenstrom's macroglobulinemia. N Engl J Med. 2015;373(6):584-6.

40. Wang ML, Rule S, Martin P, Goy A, Auer R, Kahl BS, Jurczak W, Advani RH, Romaguera JE, Williams ME, Barrientos JC, Chmielowska E, Radford J, Stilgenbauer S, Dreyling M, Jedrzejczak WW, Johnson P, Spurgeon SE, Li L, Zhang L, Newberny K, Ou Z, Cheng N, Fang B, McGreivy J, Clow F, Buggy JJ, Chang BY, Beaupre DM, Kunkel LA, et al. Targeting BTK with ibrutinib in relapsed or refractory mantle-cell lymphoma. N Engl J Med. 2013;369(6):507-16.

41. Honigberg LA, Smith AM, Sirisawad M, Verner E, Loury D, Chang B, Li S, Pan Z, Thamm DH, Miller RA, Buggy JJ. The Bruton tyrosine kinase inhibitor PCl-32765 blocks B-cell activation and is efficacious in models of autoimmune disease and B-cell malignancy. Proc Natl Acad Sci U S A. 2010;107(29):13075-80.

42. Broides A, Hadad N, Levy J, Levy R. The effects of Bruton tyrosine kinase inhibition on chemotaxis and superoxide generation in human neutrophils. J Clin Immunol. 2014;34(5):555-60.

43. Burger JA, Tedeschi A, Barr PM, Robak T, Owen C, Ghia P, Bairey O, Hillmen P, Bartlett NL, Li J, Simpson D, Grosicki S, Devereux S, McCarthy H, Coutre S, Quach H, Gaidano G, Maslyak Z, Stevens DA, Janssens A, Offner F, Mayer J, O'Dwyer M, Hellmann A, Schuh A, Siddiqi T, Polliack A, Tam CS, Suri D, Cheng $M$, et al. Ibrutinib as initial therapy for patients with chronic lymphocytic leukemia. N Engl J Med. 2015;373(25):2425-37.

44. Byrd JC, Brown JR, O'Brien S, Barrientos JC, Kay NE, Reddy NM, Coutre S, Tam CS, Mulligan SP, Jaeger U, Devereux S, Barr PM, Furman RR, Kipps TJ, Cymbalista F, Pocock C, Thornton P, Caligaris-Cappio F, Robak T, Delgado J, Schuster SJ, Montillo M, Schuh A, de Vos S, Gill D, Bloor A, Dearden C, Moreno C, Jones JJ, Chu AD, et al. Ibrutinib versus ofatumumab in previously treated chronic lymphoid leukemia. N Engl J Med. 2014;371(3):213-23.

45. Castillo JJ, Treon SP, Davids MS. Inhibition of the bruton tyrosine kinase pathway in B-cell lymphoproliferative disorders. Cancer J. 2016;22(1):34-9.

46. Treon SP, Tripsas CK, Meid K, Warren D, Varma G, Green R, Argyropoulos KV, Yang G, Cao Y, Xu L, Patterson CJ, Rodig S, Zehnder JL, Aster JC, Harris NL, Kanan S, Ghobrial I, Castillo JJ, Laubach JP, Hunter ZR, Salman Z, Li J, Cheng M, Clow F, Graef T, Palomba ML, Advani RH. Ibrutinib in previously treated Waldenstrom's macroglobulinemia. N Engl J Med. 2015;372(15):1430-40.

47. Byrd JC, Furman RR, Coutre SE, Burger JA, Blum KA, Coleman M, Wierda WG, Jones JA, Zhao W, Heerema NA, Johnson AJ, Shaw Y, Bilotti E, Zhou C, James DF, O'Brien S. Three-year follow-up of treatment-naive and previously treated patients with CLL and SLL receiving single-agent ibrutinib. Blood. 2015;125(16):2497-506 
48. Cheng G, Ye ZS, Baltimore D. Binding of Bruton's tyrosine kinase to Fyn, Lyn, or Hck through a Src homology 3 domain-mediated interaction. Proc Natl Acad Sci U S A. 1994;91(17):8152-5,

49. Fabbro SK, Smith SM, Dubovsky JA, Gru AA, Jones JA. Panniculitis in patients undergoing treatment with the bruton tyrosine kinase inhibitor ibrutinib for lymphoid leukemias. JAMA Oncol. 2015;1(5):684-6.

50. Levade M, David E, Garcia C, Laurent PA, Cadot S, Michallet AS, Bordet JC, Tam C, Sie P, Ysebaert L, Payrastre B. Ibrutinib treatment affects collagen and von Willebrand factor-dependent platelet functions. Blood. 2014; 124(26):3991-5.

51. Matsuda T, Takahashi-Tezuka M, Fukada T, Okuyama Y, Fujitani Y, Tsukada S, Mano H, Hirai H, Witte ON, Hirano T. Association and activation of Btk and Tec tyrosine kinases by gp130, a signal transducer of the interleukin-6 family of cytokines. Blood. 1995;85(3):627-33.

52. McMullen JR, Boey EJ, Ooi JY, Seymour JF, Keating MJ, Tam CS. Ibrutinib increases the risk of atrial fibrillation, potentially through inhibition of cardiac PI3K-Akt signaling. Blood. 2014;124(25):3829-30.

53. Seiter K, Stiefel MF, Barrientos J, Shaikh A, Ahmed N, Baskind P, Liu D. Successful treatment of ibrutinib-associated central nervous system hemorrhage with platelet transfusion support. Stem Cell Investig. 2016;3:27.

54. Woyach JA, Furman RR, Liu TM, Ozer HG, Zapatka M, Ruppert AS, Xue L, Li DH, Steggerda SM, Versele M, Dave SS, Zhang J, Yilmaz AS, Jaglowski SM, Blum KA, Lozanski A, Lozanski G, James DF, Barrientos JC, Lichter P, Stilgenbauer S, Buggy JJ, Chang BY, Johnson AJ, Byrd JC. Resistance mechanisms for the Bruton's tyrosine kinase inhibitor ibrutinib. N Engl J Med. 2014;370(24):2286-94.

55. Furman RR, Cheng S, Lu P, Setty M, Perez AR, Guo A, Racchumi J, Xu G, Wu H, Ma J, Steggerda SM, Coleman M, Leslie C, Wang YL. Ibrutinib resistance in chronic lymphocytic leukemia. N Engl J Med. 2014;370(24):2352-4.

56. Chiron D, Di Liberto M, Martin $P$, Huang X, Sharman J, Blecua P, Mathew S, Vijay P, Eng K, Ali S, Johnson A, Chang B, Ely S, Elemento O, Mason CE, Leonard JP, Chen-Kiang S. Cell-cycle reprogramming for PI3K inhibition overrides a relapse-specific C481S BTK mutation revealed by longitudinal functional genomics in mantle cell lymphoma. Cancer Discov. 2014;4(9):1022-35.

57. Fama R, Bomben R, Rasi S, Dal Bo M, Ciardullo C, Monti S, Rossi F, D'Agaro T, Zucchetto A, Gattei V, Gaidano G, Rossi D. Ibrutinib-naive chronic lymphocytic leukemia lacks Bruton tyrosine kinase mutations associated with treatment resistance. Blood. 2014;124(25):3831-3.

58. Ma J, Lu P, Guo A, Cheng S, Zong H, Martin P, Coleman M, Wang YL. Characterization of ibrutinib-sensitive and -resistant mantle lymphoma cells. Br J Haematol. 2014;166(6):849-61.

59. Rahal R, Frick M, Romero R, Korn JM, Kridel R, Chan FC, Meissner B, Bhang HE, Ruddy D, Kauffmann A, Farsidjani A, Derti A, Rakiec D, Naylor T, Pfister E, Kovats S, Kim S, Dietze K, Dorken B, Steidl C, Tzankov A, Hummel M, Monahan J, Morrissey MP, Fritsch C, Sellers WR, Cooke VG, Gascoyne RD, Lenz G, Stegmeier F. Pharmacological and genomic profiling identifies NFkappaB-targeted treatment strategies for mantle cell lymphoma. Nat Med. 2014:20(1):87-92.

60. Cao Y, Hunter ZR, Liu X, Xu L, Yang G, Chen J, Patterson CJ, Tsakmaklis N, Kanan S, Rodig S, Castillo JJ, Treon SP. The WHIM-like CXCR4(S338X) somatic mutation activates AKT and ERK, and promotes resistance to ibrutinib and other agents used in the treatment of Waldenstrom's macroglobulinemia. Leukemia. 2015:29(1):169-76.

61. Treon SP, Hunter ZR. A new era for Waldenstrom macroglobulinemia: MYD88 L265P. Blood. 2013:121(22):4434-6.

62. Cao Y, Yang G, Hunter ZR, Liu X, Xu L, Chen J, Tsakmaklis N, Hatjiharissi E, Kanan S, Davids MS, Castillo JJ, Treon SP. The BCL2 antagonist ABT-199 triggers apoptosis, and augments ibrutinib and idelalisib mediated cytotoxicity in CXCR4 wild-type and CXCR4 WHIM mutated Waldenstrom macroglobulinaemia cells. Br J Haematol. 2015;170(1):134-8.

63. Davis RE, Ngo VN, Lenz $G$, Tolar P, Young RM, Romesser PB, Kohlhammer $H$, Lamy L, Zhao H, Yang Y, Xu W, Shaffer AL, Wright G, Xiao W, Powell J, Jiang JK, Thomas CJ, Rosenwald A, Ott G, Muller-Hermelink HK, Gascoyne RD, Connors JM, Johnson NA, Rimsza LM, Campo E, Jaffe ES, Wilson WH, Delabie J, Smeland EB, Fisher RI, et al. Chronic active B-cell-receptor signalling in diffuse large B-cell lymphoma. Nature. 2010;463(7277):88-92.

64. Yang Y, Shaffer 3rd AL, Emre NC, Ceribelli M, Zhang M, Wright G, Xiao W, Powell J, Platig J, Kohlhammer H, Young RM, Zhao H, Yang Y, Xu W, Buggy JJ, Balasubramanian S, Mathews LA, Shinn P, Guha R, Ferrer M, Thomas C, Waldmann TA, Staudt LM. Exploiting synthetic lethality for the therapy of ABC diffuse large B cell lymphoma. Cancer Cell. 2012;21(6):723-37.
65. Covey T, Barf T, Gulrajani M, Krantz F, van Lith B, Bibikova E, van de Kar B, de Zwart E, Hamdy A, Izumi R, Kaptein A. Abstract 2596: ACP-196: a novel covalent Bruton's tyrosine kinase (Btk) inhibitor with improved selectivity and in vivo target coverage in chronic lymphocytic leukemia (CLL) patients. Cancer Res. 2015;75(15 Supplement):2596.

66. Harrington BK, Gulrajani M, Covey T, Kaptein A, Van Lith B, Izumi R, Hamdy A, Ulrich RG, Byrd JC, Lannutti BJ, Johnson AJ. ACP-196 is a second generation inhibitor of bruton tyrosine kinase (BTK) with enhanced target specificity. Blood. 2015;126(23):2908.

67. Yasuhiro T, Yoshizawa T, Hotta S, Ariza Y, Ueda Y, Kozaki R, Birkett J. Abstract 2452: ONO-4059, a novel oral Bruton's tyrosine kinase (Btk) inhibitor that demonstrates potent pharmacodynamic activity through Phosphorylated Btk (P-Btk) inhibition, in addition to effective anti-tumour activity in a TMD-8 (DLBCL) xenograft model. Cancer Res. 2013;73(8 Supplement):2452.

68. Dyer M HC, Rule S, et al.: Abstract 8553: the Bruton's tyrosine kinase (BTK) inhibitor ONO-4059: single-agent activity in patients with relapsed and refractory non-GCB-DLBCL. J Clin Oncol 2014, 32:suppl; abstr 8553.

69. Rule S SN, Salles G, et al.. Abstract 4397: a phase I study of the oral Btk inhibitor ONO-4059 in patients with relapsed/refractory B-cell lymphoma. Blood. 2013;122(21):Abstract \#4397.

70. Salles G KL, Rule S, et al:: Abstract 676: a phase I study of the oral Btk inhibitor ONO-4059 in patients with relapsed/refractory and high risk chronic lymphocytic leukaemia (CLL). Blood. 2013;122(21):Abstract \#676.

71. Tannheimer S, Liu J, Sorensen R, Yahiaoui A, Meadows S, Li L, Yue P, Keegan KS, Bates J, Tumas D, Queva C. Combination of idelalisib and ONO/GS-4059 in lymphoma cell lines sensitive and resistant to BTK inhibitors. Blood. 2015; 126(23):3697.

72. Walter HS, Rule SA, Dyer MJ, Karlin L, Jones C, Cazin B, Quittet P, Shah N, Hutchinson CV, Honda H, Duffy K, Birkett J, Jamieson V, Courtenay-Luck N, Yoshizawa T, Sharpe J, Ohno T, Abe S, Nishimura A, Cartron G, Morschhauser F, Fegan C, Salles G. A phase 1 clinical trial of the selective BTK inhibitor ONO/GS-4059 in relapsed and refractory mature B-cell malignancies. Blood. 2016;127(4):411-9.

73. Jones R, Axelrod MJ, Tumas D, Quéva C, Di Paolo J. Combination effects of B cell receptor pathway inhibitors (entospletinib, ONO/GS-4059, and idelalisib) and a BCL-2 inhibitor in primary CLL cells. Blood. 2015;126(23): 1749

74. Roberts AW, Davids MS, Pagel JM, Kahl BS, Puvvada SD, Gerecitano JF, Kipps TJ, Anderson MA, Brown JR, Gressick L, Wong S, Dunbar M, Zhu M, Desai MB, Cerri E, Heitner Enschede S, Humerickhouse RA, Wierda WG, Seymour JF. Targeting BCL2 with venetoclax in relapsed chronic lymphocytic leukemia. N Engl J Med. 2016;374(4):311-22.

75. Souers AJ, Leverson JD, Boghaert ER, Ackler SL, Catron ND, Chen J, Dayton $B D$, Ding $H$, Enschede SH, Fairbrother WJ, Huang DC, Hymowitz SG, Jin S, Khaw SL, Kovar PJ, Lam LT, Lee J, Maecker HL, Marsh KC, Mason KD, Mitten MJ, Nimmer PM, Oleksijew A, Park CH, Park CM, Phillips DC, Roberts AW, Sampath D, Seymour JF, Smith ML, et al. ABT-199, a potent and selective $\mathrm{BCL}-2$ inhibitor, achieves antitumor activity while sparing platelets. Nat Med. 2013;19(2):202-8.

76. Sharman J, Hawkins M, Kolibaba K, Boxer M, Klein L, Wu M, Hu J, Abella S, Yasenchak C. An open-label phase 2 trial of entospletinib (GS-9973), a selective spleen tyrosine kinase inhibitor, in chronic lymphocytic leukemia. Blood. 2015;125(15):2336-43.

77. Na L, Zhijian S, Ye L, Mingming G, Yilu Z, Dongping Z, Bo Z, Dan S, Shuo Z, Jing $H$, Yajuan G, Yunhang G, Zhiwei W, Min W, Lusong L, Wang L. Abstract 2597: BGB-3111 is a novel and highly selective Bruton's tyrosine kinase (BTK) inhibitor. Cancer Res. 2015;75:2597.

78. Fraser G, Cramer P, Demirkan F, Santucci Silva R, Pylypenko H, Grosicki S Janssens A, Pristupa A, Mayer J, Dilhuydy M-S, Loscertales J, Goy A, Avigdor A, Rule S, Phelps C, Mahler M, Salman M, Howes AJ, Balasubramanian S, Chanan-Khan AAA. Ibrutinib (I) plus bendamustine and rituximab (BR) in previously treated chronic lymphocytic leukemia/small lymphocytic lymphoma (CLL/SLL): a 2-year follow-up of the HELIOS study. ASCO Meet Abstr. 2016:34(15_suppl):7525.

79. Younes A, Thieblemont C, Morschhauser F, Flinn I, Friedberg JW, Amorim S, Hivert B, Westin J, Vermeulen J, Bandyopadhyay N, de Vries R, Balasubramanian S, Hellemans P, Smit JW, Fourneau N, Oki Y. Combination of ibrutinib with rituximab, cyclophosphamide, doxorubicin, vincristine, and prednisone (R-CHOP) for treatment-naive patients with CD20-positive B-cell non-Hodgkin lymphoma: a non-randomised, phase 1b study. Lancet Oncol. 2014;15(9):1019-26. 
80. Topp MS, Gokbuget N, Stein AS, Zugmaier G, O'Brien S, Bargou RC, Dombret H, Fielding AK, Heffner L, Larson RA, Neumann S, Foa R, Litzow M, Ribera JM, Rambaldi A, Schiller G, Bruggemann M, Horst HA, Holland C, Jia C, Maniar T, Huber B, Nagorsen D, Forman SJ, Kantarijan HM. Safety and activity of blinatumomab for adult patients with relapsed or refractory Bprecursor acute lymphoblastic leukaemia: a multicentre, single-arm, phase 2 study. Lancet Oncol. 2014;16(1):57-66.

81. Topp MS, Gokbuget N, Zugmaier G, Degenhard E, Goebeler ME, Klinger M, Neumann SA, Horst HA, Raff T, Viardot A, Stelljes M, Schaich M, KohneVolland R, Bruggemann M, Ottmann OG, Burmeister T, Baeuerle PA, Nagorsen D, Schmidt M, Einsele H, Riethmuller G, Kneba M, Hoelzer D, Kufer $\mathrm{P}$, Bargou RC. Long-term follow-up of hematologic relapse-free survival in a phase 2 study of blinatumomab in patients with MRD in B-lineage ALL. Blood. 2012;120(26):5185-7.

82. Fan G, Wang Z, Hao M, Li J. Bispecific antibodies and their applications. J Hematol Oncol. 2015;8:130.

83. Linder K, Gandhiraj D, Hanmantgad M, Seiter K, Liu D. Complete remission after single agent blinatumomab in a patient with pre-B acute lymphoid leukemia relapsed and refractory to three prior regimens: hyperCVAD, high dose cytarabine mitoxantrone and CLAG. Exp Hematol Oncol. 2016;5:20.

84. Rael E, Rakszawski K, Koller K, Bayerl M, Butte M, Zheng H. Treatment with rituximab and brentuximab vedotin in a patient of common variable immune deficiency-associated classic Hodgkin lymphoma. Biomarker Res. 2016:4:7.

85. Bartlett NL, Chen R, Fanale MA, Brice P, Gopal A, Smith SE, Advani R, Matous JV, Ramchandren R, Rosenblatt JD, Huebner D, Levine P, Grove L, ForeroTorres A. Retreatment with brentuximab vedotin in patients with CD30positive hematologic malignancies. J Hematol Oncol. 2014;7:24.

86. Brahmer JR, Tykodi SS, Chow LQ, Hwu WJ, Topalian SL, Hwu P, Drake CG, Camacho LH, Kauh J, Odunsi K, Pitot HC, Hamid O, Bhatia S, Martins R, Eaton K, Chen S, Salay TM, Alaparthy S, Grosso JF, Korman AJ, Parker SM, Agrawal S, Goldberg SM, Pardoll DM, Gupta A, Wigginton JM. Safety and activity of anti-PD-L1 antibody in patients with advanced cancer. N Engl J Med. 2012;366(26):2455-65.

87. Curran MA, Montalvo W, Yagita H, Allison JP. PD-1 and CTLA-4 combination blockade expands infiltrating $T$ cells and reduces regulatory $T$ and myeloid cells within B16 melanoma tumors. Proc Natl Acad Sci U S A. 2010;107(9): 4275-80.

88. Qin H, Cho M, Haso W, Zhang L, Tasian SK, Oo HZ, Negri GL, Lin Y, Zou J, Mallon BS, Maude S, Teachey DT, Barrett DM, Orentas RJ, Daugaard M, Sorensen PH, Grupp SA, Fry TJ. Eradication of B-ALL using chimeric antigen receptor-expressing T cells targeting the TSLPR oncoprotein. Blood. 2015; 126(5):629-39.

89. Maude SL, Frey N, Shaw PA, Aplenc R, Barrett DM, Bunin NJ, Chew A, Gonzalez VE, Zheng Z, Lacey SF, Mahnke YD, Melenhorst JJ, Rheingold SR, Shen A, Teachey DT, Levine BL, June CH, Porter DL, Grupp SA. Chimeric antigen receptor T cells for sustained remissions in leukemia. N Engl J Med. 2014;371(16):1507-17.

90. Zhukovsky EA, Morse RJ, Maus MV. Bispecific antibodies and CARs: generalized immunotherapeutics harnessing T cell redirection. Curr Opin Immunol. 2016;40:24-35.

\section{Submit your next manuscript to BioMed Central and we will help you at every step:}

- We accept pre-submission inquiries

- Our selector tool helps you to find the most relevant journal

- We provide round the clock customer support

- Convenient online submission

- Thorough peer review

- Inclusion in PubMed and all major indexing services

- Maximum visibility for your research

Submit your manuscript at www.biomedcentral.com/submit 